\title{
EFFECT OF ENVIRONMENTAL PERFORMANCE AND BOARD OF COMMISSIONERS ON ENVIRONMENTAL DISCLOSURES
}

\author{
Erlangga Suryarahman ${ }^{1}$ \\ Airlangga University \\ 4, Airlangga St., Surabaya, \\ Indonesia 60286 \\ erlanggasuryarahman@gmail.com*
}

\author{
Huda Trihatmoko \\ Airlangga University \\ 4, Airlangga St., Surabaya, \\ Indonesia 60286 \\ hudatrihatmoko@yahoo.com
}

\begin{abstract}
This study aims to obtain empirical evidence about the influence of environmental performance, board size of commissioners, independent commissioners, and the board of commissioners meetings on environmental disclosure. The sample of this study was 81 mining companies participating in PROPER which were listed on the Indonesia Stock Exchange during the 2014-2018 period. Environmental disclosure was assessed with GRI-4 guidelines and data were analyzed using multiple linear regression analysis. The results of this study indicate that environmental performance and independent commissioners have no effect on environmental disclosure, on the other hand, the board size of commissioners and the board of commissioners meeting have an effect on environmental disclosure.
\end{abstract}

Keywords: Enviromental disclosure; environmental performance; board size of commissioners; independent commissioners; board of commissioners meeting

\section{ABSTRAK}

Penelitian ini bertujuan untuk memperoleh bukti secara empiris mengenai pengaruh kinerja lingkungan, ukuran dewan komisaris, komisaris independen dan rapat dewan komisaris terhadap pengungkapan lingkungan. Sampel penelitian ini sebanyak 81 perusahaan pertambangan peserta PROPER yang terdaftar di Bursa Efek Indonesia selama periode 2014-2018. Pengungkapan lingkungan dinilai dengan pedoman GRI-4 dan data dianalisis menggunakan analisis regresi linier berganda. Hasil dari penelitian ini menunjukkan bahwa kinerja lingkungan dan komisaris independen tidak berpengaruh terhadap pengungkapan lingkungan, disisi lain ukuran dewan komisaris dan rapat dewan komisaris berpengaruh terhadap pengungkapan lingkungan.

Kata Kunci: Pengungkapan lingkungan; kinerja lingkungan; ukuran dewan komisaris; komisaris independen; rapat dewan komisaris

JEL Classification: M410; G340

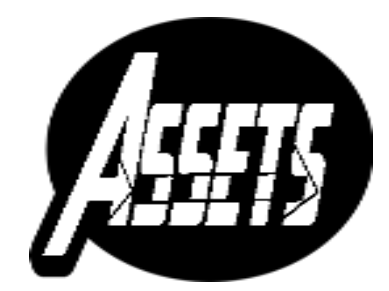

ASSETS

Jurnal Akuntansi dan Pendidikan

Vol. 10 No. 1

Page 1 - 10

Madiun, April 2021

p-ISSN: 2302-6251

e-ISSN: 2477-4995

Article History Submitted: February 5, 2020 Accepted:

November 22, 2020 


\section{INTRODUCTION}

The rise of environmental problems that occur and many people talk about one of them caused by the many negligences committed by the company. The indifference that arises as a result of the activities carried out by the company by not considering or not caring about the pros and cons of the waste generated on the surrounding environmental pollution. Industrial activities in Indonesia still need to be considered by the government to reduce all environmental problems that occur. In Indonesia, environmental reporting must be reported following UU 40 Tahun 2007 (Pemerintah Indonesia, 2007). According to existing regulations that companies that use nature as a business activity are expected to manage environmental responsibility. Besides, Article 66 paragraph $2 \mathrm{c}$ requires limited liability of companies as their responsibility to produce accountability reports in annual reports related to the environment that can be used by relevant parties and increasing company accountability.

Environmental problems are not only a concern for consumers and the government, but also a special concern for investors. Investors are interested in companies that implement good environmental management in its preservation. Companies should not merely pursue profit as the main goal, but the company must also pay attention to, and even be involved in protecting the environment (Tarmizi, Octavianti, \& Anwar, 2012). Companies are not only competing economically, but more than that care for to the welfare of the people as part of their responsibilities (Kurniawan, 2017).

The problem of environmental pollution still often occurs in Indonesia, this is due to the unbalanced number of companies with an improved environment and an adequate increase in society. Many mining companies do not pay attention to the environment by destroying the environment and damaging human rights. For example the case of a child who was killed by a Samarinda mine pit, environmental pollution by PT. Mitrabara Adiperdana in Malinau, PT. Freeport affecting environmental impacts (Ula, 2018). If related to the phenomenon of environmental pollution where mining activities are one of the events that most have an impact on the environment, then this study uses a sample of mining companies listed on the Indonesia Stock Exchange (IDX).

Stakeholder Theory explains that the company's goals are not solely for the needs of private companies but also for the interests of outsiders in environmental companies (Terzaghi, 2012). Seeing the number of investors who care about environmental conditions, then a company must improve environmental performance in order to attract investors or stakeholders to invest their shares. Agency theory states that there are two different sides of interest, namely agents (management) and principals (shareholders) (Jensen \& Meckling, 1976), to provide corporate responsibility for these two interests by using a corporate governance system, where Corporate Social Responsibility is required by a company as a form of attention to the environment. There are differences in objectives that can lead to conflicts that occur in management companies related to shares so that conflicts of interest (agency problems) (Leo, 2012).

The board of commissioners is one of the specialized organs contained in the corporate governance structure, which consists of the board size of commissioners, independent commissioners, and the number of board meetings. The board of commissioners acts as a supervisor in a company, while an independent commissioner serves as a balancing force in decision making from the board of commissioners. In general, more careful management supervision by an independent commissioner reduces the estimation of fraud and errors in the information provided by the manager, which means the more trust the independent board of commissioners, the less chance 
of fraud in the annual statements according to the environmental report (Ariningtika \& Kiswara, 2013). Board of Commissioners' meetings is usually used to focus, consider and assess the company's strategic objectives (Ariningtika \& Kiswara, 2013).

This study aims to see the effect of environmental performance, the board size of commissioners, independent commissioners, and the number of board of commissioners meetings on environmental disclosure. Based on the background above, this study aims to obtain empirical evidence about the influence of environmental performance, the board size of commissioners, independent commissioners, and the number of board of commissioners' meetings on environmental disclosure.

\section{METHOD}

This study uses data from annual financial reports available on the Indonesia Stock Exchange (IDX). The chosen sector is the mining sector. The total amount of data is 100 mining companies listed on the Indonesia Stock Exchange in 2014-2018. Based on population selection criteria, the study sample was 81 companies, as shown in table 1.

Table 1 Population and Research Samples

\begin{tabular}{lc}
\hline \multicolumn{1}{c}{ Information } & Number of Samples \\
\hline Mining companies listed on PROPER and listed on the IDX & 100 \\
Companies that do not meet the criteria: & 12 \\
$\begin{array}{l}\text { Companies that do not publish annual reports } \\
\text { Companies that do not have complete data needed in }\end{array}$ & 7 \\
research & 81 \\
\hline
\end{tabular}

The environmental performance is a company performance that cares about the environment. Companies that disclose a lot of information about the environment in their annual reports tend to have good environmental performance (Aulia \& Agustina, 2015). Environmental performance can be measured using the Company Performance Rating Rating Program in environmental management (PROPER). The higher the PROPER value obtained by the company, the environmental disclosure assessed by the GRI-G4 criteria will also be higher (Dewi \& Yasa, 2017).

The board of commissioners is the core of the management of the company whose job is to ascertain whether the company's strategy is running as expected, overseeing management and increasing accountability (Supatminingsih \& Wicaksono, 2016). Variable Board Size of Commissioners is measured by the total number of members of the board of commissioners in an annual report of the company.

Based on Bapepam's decision No. 29/PM/2004 independent commissioners are defined as members of the board of commissioners who come from outside the issuer or public company that is not affiliated with directors, other members of the board of commissioners and majority shareholders and are free from relationships that can result in them being unprofessional by prioritizing personal interests or a number of a group. The Independent Commissioner variable is measured by the number of independent commissioners divided by the total number of commissioners.

The board of commissioners meeting is is held to obtain joint results on what companies must do to improve the company. The board of commissioners meeting variable is measured by counting the number of meetings conducted by the board of commissioners for one year. 
Environmental Disclosure is one of the ways implemented by the company to provide information to outside parties related to the company and its impact on the surrounding environment and social environment (Nofianti, Uzliawati, \& Sarka, 2015). Environmental disclosure variables were measured using the Global Reporting Initiative (GRI-G4). The GRI index has the most complete format in providing information (Setyorini \& Suranta, 2015).

Data analysis uses descriptive statistics and multiple linear regression. Formulation testing using multiple linear regression analysis is:

Enviromental Disclosure $(E D)=\alpha+\beta$ Enviromental Performance $(E P)+\beta$ Board Size of Commissioners (BS) $+\beta$ Independent Commissioners (IC) $+\beta$ Board of Commissioners Meeting $(\mathrm{BM})+\varepsilon$

\section{RESULT AND DISCUSSION}

Descriptive statistical test results from environmental performance, Board of Commissioners Size, Independent Commissioners, Board of Commissioners Meeting, and Environmental Disclosure at mining companies listed on the Indonesia Stock Exchange in 2014-2018 are present in table 2.

Table 2 Descriptive Statistics

\begin{tabular}{cccccc}
\hline & $\mathrm{N}$ & Minimum & Maximum & Mean & Std. Deviation \\
\hline ED & 81 & 0,118 & 0,529 & 0,249 & 0,092 \\
EP & 81 & 2 & 5 & 3,410 & 0,667 \\
BS & 81 & 2 & 13 & 5,370 & 1,997 \\
IC & 81 & 0,300 & 1 & 0,442 & 0,162 \\
BM & 81 & 2 & 15 & 6,560 & 3,978 \\
\hline
\end{tabular}

Table 2 shows that in general, the lowest minimum, maximum, mean and standard deviation values are in the environmental disclosure variable. The minimum ED value of 0.118 is owned by PT. Energi Mega Persada in 2014. The maximum ED value of 0.529 is owned by PT. Timah (Persero) in 2016. The minimum EP value of 2 is owned by PT. Golden Energy Mines in 2014. The maximum EP value of 5 is owned by PT. Medco Energi Internasional in 2016. The minimum BS value of 2 is owned by PT. J Resources Asia Pacific 2016. The maximum BS value of 13 is owned by PT. Bumi Resources in 2015. The minimum IC value of 0.300 is owned by PT. Vale Indonesia in 2016. The maximum IC value of 1 is owned by PT. Toba Bara Sejahtera in 2018. The minimum BM value of 2 is owned by PT. Bayan Resources in 2014. The maximum BM value of 15 is owned by PT. Timah (Persero) in 2016. The standard deviation values of all variables when compared with the average value indicate that the standard deviation values are smaller or below the average value which means the level of data distribution of all variables is relatively small or homogeneous, so in terms of this shows that the data for all variables are not so varied.

Table 3 Results of Multiple Linear Regression Analysis

\begin{tabular}{lccc}
\hline \multicolumn{1}{c}{ Model } & $\mathrm{B}$ & $\mathrm{t}$ & Sig. \\
\hline (Constant) & 0,214 & 2,983 & 0,004 \\
EP & $-0,026$ & $-1,840$ & 0,070 \\
BS & 0,014 & 2,745 & 0,008 \\
IC & $-0,011$ & $-0,163$ & 0,871 \\
BM & 0,008 & 3,361 & 0,001 \\
\hline
\end{tabular}




\section{Effect of Environmental Performance on Environmental Disclosure}

Based on the results of table 2, it is known that the t-value is -1.840 , with a significance value of 0.070 . The significance level of 0.070 is more significant than 0.05 , which means that environmental performance does not affect environmental disclosure. This is because not many environmental disclosures were revealed by the sample companies that participated in the PROPER in their annual reports, as well as the mean environmental disclosure during the observation period of 24.9 percent from 100 percent. It shows that the sample companies that followed the PROPER mean revealed 8 items of environmental information out of a total of 34 GRI index items.

The more companies participate in environmental activities, indirectly add disclosures that companies must report about the environment in the annual report. This relates to transparency to increase the confidence of outsiders how concerned companies take part and are responsible for their environment. But what happens is the opposite, the role of the company regarding the environment is very minimal resulting in disclosure about the environment in the annual report is also very little. This illustrates that good or bad corporate environmental performance does not affect environmental disclosure. So the increasingly good environmental performance of a company is not necessarily followed by an increase in environmental disclosure in its annual report. Management considers that environmental performance does not provide much benefit for the compensation received so there is no need to provide so much disclosure. This large amount of environmental disclosure is usually aimed at large companies. This is because to conduct environmental disclosure requires additional costs that are high enough that small companies will provide a competitive disadvantage if doing environmental disclosure (Meng, Zeng, Shi, Qi, \& Zhang, 2014).

Stakeholders usually only pay attention to the ups and downs of share prices and company profits in decision making, without paying attention to other information such as the company's environmental performance. Companies also tend to disclose good information and withhold information that hurts the company. Based on the results of this study indicate that mining companies in Indonesia are still lacking in presenting evidence of environmental performance information. Companies tend to be difficult to express through what activities have been carried out by the company as reflected in the items required in environmental disclosure. These results indicate that management awareness is still low to follow the required environmental criteria, especially those reflected in environmental disclosure items because these items are objective and can reflect the difference between good environmental performance and poor environmental performance. The results of this study are the same as the research of Darma, Arza \& Halmawati (2019), Pramesti \& Syafruddin (2016), Halmawati \& Oktalia (2015) that environmental performance does not affect environmental disclosure.

\section{Effect of Board Size of Commissioners on Environmental Disclosure}

Based on the results of table 2, it is known that the t-value is 2.745 , with a significance value of 0.008 . The significance level of 0.008 is less than 0.05 , which means that the board size of commissioners has a positive effect on environmental disclosure. The higher the board size of commissioners, the supervision conducted in the internal management system will be more effective in minimizing agency conflicts that occur between the majority shareholders and management. The board of commissioners is responsible for ensuring the implementation of the company's strategy and for effective operations because the board of commissioners is considered the highest

This work is licensed under a Creative Commons Attribution-ShareAlike 4.0 International License. 
internal control mechanism capable of carrying out good management mechanisms in overseeing management as following the agency theory put forward by Michael C. Jensen and William H. Meckling in 1976 (Mukhtaruddin, Saftiana, \& Dwikatama, 2018).

The size of the board of commissioners in question is a large number of members of the board of commissioners in a company. According to UU 74 Tahun 2007 explain that the duty of the board of commissioners is to be responsible for conducting supervision in general or specifically in accordance with the articles of association and providing advice to directors (Pemerintah Indonesia, 2007). The duties of the board of commissioners are explained in more detail, namely the board of commissioners oversees management policies, the course of management in general, both regarding the company and the business of the company and provides advice to directors in the interests of the company and in accordance with the aims and objectives of the company.

The board size of commissioners can cover deficiencies due to information asymmetry. The large board size of commissioners indirectly results in exchanges between commissioners regarding experiences and ideas that can support the management supervision process. The large board size of commissioners is also considered effective because they bring more knowledge and experience and also far better advice so that the environmental disclosure process can be optimized $(\mathrm{H}$. Setyawan \& Kamilla, 2015). This is also in line with Supriyono, Almasyhari, Suhardjanto, \& Rahmawati (2015) and Cahyani \& Suryaningsih (2016) that the increasing board size of commissioners makes it easier to control the CEO and of course provides greater power of advice to management regarding better environmental disclosure measures if compared to fewer board sizes of commissioners.

Agreeing with this, Solikhah \& Winarsih (2016), Kathy Rao, Tilt \& Lester (2012) stated that the larger the size of the board of commissioners, the wider the environmental disclosure. This further increases the size of the board of commissioners, so it will easier to supervise the CEO (top management) and the monitoring conducted is far more effective so that the process of disclosure of environmental activity reports can be optimized.

\section{Effect of Independent Commissioners on Environmental Disclosure}

Based on the results of table 2, it is known that the value of $t-0.163$ with a significance value of 0.871 . The significance level of 0.871 is more significant than 0.05 , which means that independent commissioners do not influence environmental disclosure. This is due to the role of independent commissioners who do not directly carry out company activities so that they do not influence decision making such as in making environmental disclosures. The nature of independent directors who should be more credible and not having the interests of non-independent directors is not strong enough to influence decisions in making environmental disclosures. This according to Supatminingsih \& Wicaksono (2016) occurs because there is a tendency that independent commissioners owned by companies only comply with applicable regulations, namely the requirement for a minimum number of independent commissioners of $30 \%$ of the total number of existing commissioners. Things like this might happen because the election and appointment of independent commissioners is done less effectively. This is an important issue that many independent commissioners actually do not have the ability and are unable to show their independence or are actually not independent so that the supervisory function cannot function properly. 
That way, the existence of an independent commissioner does not affect environmental disclosure (Effendi, 2017).

The results of this study are in line with Effendi, Uzliawati \& Yulianto (2012) showing that the roles and responsibilities of independent commissioners in companies in Indonesia, especially in mining companies, do not function as they should, whereas independent commissioners have a major influence on management decisions, including disclosure environmental information in the annual report. This relates to the approval of the independent commissioners carried out by the minority shareholders who incidentally did not participate in controlling the company at the general meeting of shareholders so that it did not affect much in environmental disclosure in the annual report. This was also conveyed by Suhardjanto, Purwanto, Sari, \& Setiany (2018) that an independent commissioner is an outside party that is not unrelated to the directors and other board of commissioners so that it does not affect environmental disclosure.

The inability of independent commissioners to influence decision making related to the disclosure of company environmental information can be influenced by several factors including concurrent positions. Independent commissioners in several companies are on average concurrently serving as independent commissioners or directors in other companies. Some independent commissioners are people who have multiple positions, whether as commissioners, directors or government positions. Multiple positions can cause independent commissioners to not focus on overseeing a company that is his responsibility. The results of this study are the same as the research of Pratama \& Rahardja (2013), Setyawan \& Zulaikha (2012) that independent commissioners do not affect environmental disclosure.

\section{Effect of Board of Commissioners Meeting on Environmental Disclosure}

Based on the results of table 2, it is known that the value of $t$ is 3.361 , with a significance value of 0.001 . The significance level of 0.001 is less than 0.05 , which means that the board of commissioners meeting has a positive effect on environmental disclosure. This according to Ariningtika \& Kiswara (2013) occurs because the board of commissioners meeting is an intensive forum to accommodate, monitor, direct, and evaluate the company's strategic implementation. One of the agenda of the board of commissioners meeting is regarding the evaluation of the implementation of social responsibility and environmental development programs conducted by the company and also scheduled in the board of commissioners meeting regarding the application of environmental, social and good corporate governance programs.

The more frequent meetings by the board of commissioners, the smaller the company's managed accruals. This indicates that the more frequently the board of commissioners meets, the supervisory function by management becomes more effective. In this way, the responsibility of the board of commissioners for environmental disclosure becomes wider (Effendi, 2017). In addition, meetings conducted by the board of commissioners have been running effectively, meaning that all members of the board of commissioners prioritize the interests of the company rather than personal or group interests related to environmental disclosure.

The high frequency of the board of commissioners meeting is recommended in the Peraturan Otoritas Jasa Keuangan No. 33 Tahun 2014 about Directors and Board of Commissioners of Issuers or Public Companies (Pemerintah Indonesia, 2014). This means that the more intensity the board of commissioners conducts meetings, the more things that are evaluated. One of them is the company's compliance in disclosing 
information about social and environmental responsibility. The results of this study are the same as the research of Pratama \& Rahardja (2013), Kharis \& Suhardjanto (2012), Setyawan \& Zulaikha (2012) which states that the board of commissioners' meeting has a positive effect on environmental disclosure.

\section{CONCLUSION}

Good environmental disclosure is believed to be used by the company to create added value for stakeholders. The results of this study prove that the board size of commissioners and board of commissioners meeting affect the company's environmental disclosure. That explains that the greater the board size of commissioners, the easier it is to supervise the CEO (top management) and the monitoring conducted is far more effective so that the process of disclosure of environmental activity reports can be optimized. Board of commissioners meeting that are held periodically and heavily will provide added value in providing relevant information that discusses the suitability of company operations with company policies and strategies. On the other hand, the results of this study explain that there is no influence between environmental performance and independent commissioners on the company's environmental disclosure. This is because the stakeholders usually only pay attention to the ups and downs of share prices and company profits in decision making, without paying attention to other information such as the company's environmental performance. Independent commissioners do not affect environmental disclosure because of the role of independent commissioners who do not directly carry out company activities so they do not have much influence in decision making, especially in terms of environmental disclosure.

This study also has limitations. Firstly, environmental disclosure is more disclosed in sustainability reporting than in the annual report because in the annual report companies still rarely want to disclose related to the environment. Second, there is an element of researcher subjectivity in determining the disclosure of confusion in accordance with items on the GRI index, so that environmental disclosure for the same indicator can produce different assumptions between researchers. Future studies are suggested to focus more on companies that have sustainability reporting in environmental disclosure to get more specific results and also add other related variables to environmental disclosure so that they can provide a broader picture of what factors affect environmental disclosure.

\section{REFERENCES}

Ariningtika, P., \& Kiswara, E. (2013). Pengaruh Praktik Tata Kelola Perusahaan Yang Baik Terhadap Pengungkapan Lingkungan Perusahaan (Studi Empiris Pada Perusahaan Pertambangan yang Terdaftar di Bursa Efek Indonesia Tahun 20102011). Diponegoro Journal of Accountinng, 2(2), 1-11.

Aulia, F. Z., \& Agustina, L. (2015). Pengaruh Karakteristik Perusahaan, Kinerja Lingkungan, dan Liputan Media Terhadap Environmental Disclosure. Accounting Analysis Journal, 4(3), 1-8. https:/ / doi.org/10.15294/aaj.v4i3.8306

Cahyani, C., \& Suryaningsih, R. (2016). The Effect of Leverage, Board of Commissioner, Foreign Ownership, Company Age, and Company Size Towards the Disclosure of Corporate Social Responsibility (CSR) Implementation. Accounting and Finance Review, 1(1), 27-33.

Darma, B. D., Arza, F. I., \& Halmawati. (2019). Pengaruh Pengungkapan Media, Kinerja Lingkungan Dan Kepemilikan Asing Terhadap Pengungkapan Corporate Social Responsbility. Jurnal Eksplorasi Akuntansi, 1(1), 78-89. 
Dewi, I. A. P. O. Y., \& Yasa, G. W. (2017). Pengaruh Ukuran Perusahaan, Profitabilitas, Tipe Industri dan Kinerja Lingkungan Terhadap Environmental Disclosure. EJurnal Akuntansi, 20(3), 2362-2391.

Effendi, B. (2017). Ukuran Perusahaan, Jumlah Rapat Dewan Komisaris dan Environmental Disclosure di Indonesia. Jurnal Bisnis Dan Manajemen, 3(2), 1325.

Effendi, B., Uzliawati, L., \& Yulianto, A. S. (2012). Pengaruh Dewan Komisaris terhadap Environmental Disclosure pada Perusahaan Manufaktur yang Listing di BEI Tahun 2008-2011. Simposium Nasional Akuntansi XV, 1-25.

Halmawati, H., \& Oktalia, D. (2015). Pengaruh Kinerja Lingkungan dan Profitabilitas Terhadap Corporate Social Responsibility Disclosure dalam Laporan Tahunan Perusahaan. Jurnal Kajian Manajemen Bisnis, 4(2), 1-15.

Jensen, M. C., \& Meckling, W. H. (1976). Theory of the firm: Managerial behavior, agency costs and ownership structure. Journal of Financial Economics, 1, 305360. https://doi.org/10.1016/0304-405X(76)90026-X

Kathy Rao, K., Tilt, C. A., \& Lester, L. H. (2012). Corporate governance and environmental reporting: An Australian study. Corporate Governance: The International Journal of Business in Society, 12(2), 143-163. https://doi.org/10.1108/14720701211214052

Kharis, A., \& Suhardjanto, D. (2012). Corporate Governance Dan Ketaatan Pengungkapan Wajib Pada Badan Usaha Milik Negara. Jurnal Keuangan Dan Perbankan, 16(1), 37-44.

Kurniawan, P. S. (2017). Studi Empiris Faktor-faktor yang Mempengaruhi Pengungkapan Sosial dan Lingkungan Perusahaan Manufaktur dengan Mekanisme Corporate Governance Sebagai Variabel Pemoderasi. Jurnal Ekonomi Dan Bisnis Airlangga, 27(1), 1-41. https:/ / doi.org/10.20473/jeba.v27i12017.5574

Leo, J. (2012). Pengaruh Konsentrasi Kepemilikan, Ukuran Perusahaan dan Mekanisme Good Corporate Governance Terhadap Pengungkapan dalam Laporan Tahunan Studi Perusahaan Manufaktur di BEI. Berkala Ilmiah Mahasiswa Akuntansi Widya Mandala, 1(1), 123-129.

Meng, X. H., Zeng, S. X., Shi, J. J., Qi, G. Y., \& Zhang, Z. B. (2014). The relationship between corporate environmental performance and environmental disclosure: An empirical study in China. Journal of Environmental Management, 145, 357467.

Mukhtaruddin, Saftiana, Y., \& Dwikatama, P. A. (2018). Firm's Characteristics, Corporate Governance Quality and Corporate Social Responsibility Disclosure. Sriwijaya International Journal of Dynamic Economics and Business, 2(3), 193212.

Nofianti, N., Uzliawati, L., \& Sarka, S. (2015). Pengaruh Corporate Governance terhadap Environmental Disclosure dengan Environmental Performance sebagai Variabel Moderating. Trikonomika, 14(1), 38-46. https://doi.org/10.23969/trikonomika.v14i1.590

Pemerintah Indonesia. (2007). Undang-Undang Perseroan Terbatas Pasal 74 Tahun 2007. Lembaran RI Tahun 2007 No. 84. Jakarta: Sekretariat Negara.

Pemerintah Indonesia. (2014). Peraturan Otoritas Jasa Keuangan No. 33 Tahun 2014. Lembaran RI Tahun 2014 No. 375. Jakarta: Sekretariat Negara.

Pramesti, A. H., \& Syafruddin, M. (2016). Kualitas Pengungkapan Lingkungan: Perspektif Dari Kinerja Lingkungan, Corporate Governance, Dan Relevansi Nilai. Universitas Diponegoro. 
Pratama, A. G., \& Rahardja, R. (2013). Pengaruh Good Corporate Governance dan Kinerja Lingkungan Terhadap Pengungkapan Lingkungan (Studi Empiris Pada Perusahaan Manufaktur dan Tambang yang Terdaftar Pada Bursa Efek Indonesia (BEI) dan Termasuk dalam PROPER Tahun 2009-2011). Universitas Diponegoro.

Setyawan, B., \& Zulaikha, Z. (2012). Analisis Pengaruh Praktik Good Corporate Governance dan Manajemen Laba terhadap Corporate Environmental Disclosure (Studi Empiris pada Perusahaan yang terdaftar di BEI dan PROPER tahun 20082010). Universitas Diponegoro.

Setyawan, H., \& Kamilla, P. (2015). Impact of Corporate Governance on Corporate Environmental Disclosure: Indonesian Evidence. International Conference on Trends in Economics, Humanities and Management, 13-18.

Setyorini, M. E., \& Suranta, S. (2015). Pengaruh Earnings Management Terhadap Corporate Environmental Responsibility Disclosure dengan Mekanisme Corporate Governance sebagai Variabel Pemoderasi (Studi Empiris Perusahaan Manufaktur yang Terdaftar di BEI Tahun 2008- 2011). Jurnal Akuntansi Dan Bisnis, 15(2), 120-136. https:// doi.org/10.20961/jab.v15i2.182

Solikhah, B., \& Winarsih, A. M. (2016). Pengaruh Liputan Media, Kepekaan Industri, dan Struktur Tata Kelola Perusahaan terhadap Kualitas Pengungkapan Lingkungan. Jurnal Akuntansi Dan Keuangan Indonesia, 13(1), 1-22. https:// doi.org/10.21002/jaki.2016.01

Suhardjanto, D., Purwanto, P., Sari, K., \& Setiany, E. (2018). Corporate governance and social disclosure: a comparative study of listed hospitality industries in South East Asia. International Journal of Trade and Global Markets, 11(1-2), 21-30.

Supatminingsih, S., \& Wicaksono, M. (2016). Pengaruh Corporate Governance Terhadap Pengungkapan Lingkungan Perusahaan Bersertifikasi ISO-14001 di Indonesia. Jurnal Akuntansi Dan Pajak, 17(1), 32-48. https://doi.org/10.29040/jap.v17i01.54

Supriyono, E., Almasyhari, A. K., Suhardjanto, D., \& Rahmawati, S. (2015). The impact of corporate governance on corporate social disclosure: comparative study in South East Asia. International Journal of Monetary Economics and Finance, 8(2), 143-161.

Tarmizi, R., Octavianti, D., \& Anwar, C. (2012). Analisis Pengungkapan Akuntansi Lingkungan Terhadap Pertanggungjawaban Sosial Industri Kimia (Studi Kasus Pada Sosial Industri Kimia di Kota Bandar Lampung). Jurnal Akuntansi Dan Keuangan, 3(1), 21-38.

Terzaghi, M. T. (2012). Pengaruh Earning Management dan Mekanisme Corporate Governance Terhadap Pengungkapan Tanggung Jawab Sosial Perusahaan Manufaktur Yang Terdaftar di Bursa Efek Indonesia. Jurnal Ekonomi Dan Informasi Akuntansi, 2(1), 31-47.

Ula, H. (2018). The Urgency of Human Rights Audit on Mining Company in Indonesia. Advances in Economics, Business and Management Research, 59, 119-123. 